\title{
Imaging of human pancreatic cancer xenografts by single-photon emission computed tomography with ${ }^{99 \mathrm{~m}}$ Tc-Hynic-PEG-AE105
}

\author{
XIN ZHANG $^{1 *}$, YE TIAN ${ }^{2,3^{*}}$, FANGFANG SUN $^{1}$, HONGBO FENG $^{1}$, \\ CHUN YANG $^{1}$, XIAOYAN GONG ${ }^{1}$ and GUANG TAN ${ }^{3}$ \\ ${ }^{1}$ Department of Nuclear Medicine, First Affiliated Hospital, Dalian Medical University, Dalian, Liaoning 116011; \\ ${ }^{2}$ Department of Emergency Medicine, Affiliated Hospital, Luzhou Medical College, Luzhou, Sichuan 646000; \\ ${ }^{3}$ Department of General Surgery, First Affiliated Hospital, Dalian Medical University, Dalian, Liaoning 116011, P.R. China
}

Received August 29, 2014; Accepted May 20, 2015

DOI: $10.3892 / 01.2015 .3504$

\begin{abstract}
The elevated expression of urokinase-type plasminogen activator receptor (UPAR) is associated with the poor prognosis of pancreatic cancer patients. Thus, UPAR is a promising candidate as a molecular target for the non-invasive imaging of pancreatic cancer. The present study aimed to develop a technetium-99m $\left({ }^{99 \mathrm{~m}} \mathrm{Tc}\right)$-labeled uPAR-binding peptide for non-invasive single-photon emission computed tomography (SPECT) assessment of uPAR expression in pancreatic cancer xenograft models. A linear high-affinity uPAR peptide antagonist, Hynic-PEG-AE105, was labeled with ${ }^{99 \mathrm{~m}} \mathrm{Tc}$. Human uPAR-positive pancreatic cancer BxPC-3 cells were inoculated into nude mice. SPECT was performed in the pancreatic cancer xenograft mice models. The results showed that the rate of the ${ }^{99 \mathrm{~m}} \mathrm{Tc}$ labeling of Hynic-PEG-AE105 was 97.72 $\pm 1.73 \%$. The tumor uptake of ${ }^{99 \mathrm{~m}}$ Tc-Hynic-PEG-AE105 was higher than the control inactive peptide ${ }^{99 \mathrm{~m}} \mathrm{Tc}-\mathrm{Hynic}-\mathrm{PEG}-\mathrm{AE} 105 \mathrm{mut}$ at $4 \mathrm{~h}(3.37 \pm 0.11$ vs. $1.36 \pm 0.18 ; \mathrm{P}<0.001)$ and $6 \mathrm{~h}$ $(3.64 \pm 0.25$ vs. $1.28 \pm 0.20 ; \mathrm{P}<0.001)(\mathrm{n}=10)$. Moreover, a significant correlation was observed between the tumor uptake of ${ }^{99 \mathrm{~m} T c-H y n i c-P E G-A E 105}$ and uPAR expression $(\mathrm{r}=0.791, \mathrm{P}=0.006)$. In conclusion, in the present study, a peptide-based SPECT tracer, ${ }^{99 \mathrm{~m} T c-H y n i c-P E G-A E 105,}$ with a high purity and specific radioactivity was synthesized. ${ }^{99 \mathrm{~m} T c-H y n i c-P E G-A E 105}$ is a promising agent for the non-invasive determination of UPAR expression in pancreatic cancer.
\end{abstract}

Correspondence to: Professor Guang Tan, Department of General Surgery, First Affiliated Hospital, Dalian Medical University, 222 Zhong Shan Lu, Dalian, Liaoning 116011, P.R. China

E-mail: tangsci@126.com

*Contributed equally

Key words: urokinase-type plasminogen activator receptor, pancreatic cancer, integrin, single-photon emission computed tomography

\section{Introduction}

Pancreatic cancer is the 13th most common type of cancer, and the 8th leading cause of cancer-related mortality, accounting for $6.9 \%$ of all cancer-related mortalities, worldwide (1). The initial symptoms of pancreatic cancer are often nonspecific, such as nausea, fatigue, jaundice, weight loss, light-colored stools, dark urine and pain in the back or stomach area (2). Pancreatic cancer may be treated with surgery, radiotherapy or chemotherapy (3). Chemotherapy and radiation therapy are important adjuvant or neoadjuvant therapies, particularly for patients with unresectable disease (4). Pancreatic cancer has an extremely poor prognosis; the median survival time for all patients is 4-6 months, and the overall five-year survival rate is $7.2 \%$ (1). Emerging evidence suggests that the serine-protease urokinase-type plasminogen activator (uPA) and its receptor (uPAR) are significant in pancreatic cancer invasion and metastasis (5-7). Overexpression of uPAR in pancreatic cancer has been determined to be a strong and independent predictor of short overall survival (6). uPAR is recognized as a novel marker of cancer invasion and metastasis, and is a promising candidate as a molecular target for cancer therapy $(8,9)$. The ability to visualize and quantify uPAR expression non-invasively in vivo is required for the potential clinical application of anticancer therapy based on the UPA/uPAR system $(10,11)$.

Therefore, in the present study, a high-affinity 9-mer peptide antagonist of UPA-UPAR (AE105) was selected to develop a technetium-99m $\left({ }^{99 \mathrm{~m}} \mathrm{Tc}\right)$-labeled tracer for non-invasive single-photon emission computed tomography (SPECT) assessment of uPAR expression in pancreatic cancer. ${ }^{99 \mathrm{~m} T c-H y n i c-P E G-A E 105}$ was prepared, together with a non-binding version ( $\left.{ }^{99 \mathrm{~m}} \mathrm{Tc}-\mathrm{Hynic}-\mathrm{PEG}-\mathrm{AE} 105 \mathrm{mut}\right)$ as a control, and the quantitative association between tracer uptake and UPAR expression was investigated in pancreatic tumor tissues.

\section{Materials and methods}

Reagents. All commercially available chemical reagents were used without further purification. The peptide antagonist HYNIC-PEG-AE105 and a non-binding variant 
of HYNIC-PEG-AE105 (HYNIC-PEG-AE105mut) were synthesized (purity $>95 \%$ ) by Shanghai Apeptide Co., Ltd. (Shanghai, China). The sequences of HYNIC-PEG-AE105 and HYNIC-PEG-AE105mut were D-Cha-F-s-r-Y-L-W-S and D-Cha-F-s-r-Y-L-E-S, respectively. ${ }^{99 \mathrm{~m}} \mathrm{Tc}_{-} \mathrm{O}_{4}{ }^{-}$was obtained from Beijing Atom HighTech Co., Ltd. (Beijing, China). $\mathrm{S}_{\mathrm{n}} \mathrm{CL}_{2} \cdot \mathrm{H}_{2} \mathrm{O}$ (purity $>99.99 \%$ ) was purchased from Gracia Chengdu Chemical Technology Co., Ltd. (Chengdu, China). Tricine (purity $>99 \%$ ) was purchased from Sigma-Aldrich (St. Louis, MO, USA).

Labeling of peptides. ${ }^{99 \mathrm{~m}} \mathrm{Tc}$ peptide labeling was performed at room temperature using Tricine as a co-ligand and $\mathrm{S}_{\mathrm{n}} \mathrm{CL}_{2}$ as the reducing agent. Tricine and ${ }^{99 \mathrm{~m}} \mathrm{Tc}^{-} \mathrm{O}_{4}{ }^{-}$(specific activity, $370 \mathrm{MBq} / \mathrm{ml}$ ) in $100 \mu 1 \mathrm{~S}_{\mathrm{n}} \mathrm{CL}_{2} \bullet \mathrm{H}_{2} \mathrm{O}$ was diluted in $80 \mu 1$ Hynic-PEG-AE105 dissolved in HEPES $(1 \mathrm{mg} / \mathrm{ml}$; $\mathrm{pH}$ 5.5) and incubated at room temperature. The labeling was optimized by changing the reaction time $(0,5,10,20,30$ and $60 \mathrm{~min})$, dosage of $\mathrm{S}_{\mathrm{n}} \mathrm{CL}_{2}(40,60,80,100,120$ and $150 \mu \mathrm{g})$, dosage of Tricine $(20,40,60,80$ and $100 \mathrm{mg})$, dosage of Hynic-PEG-AE105 $(40,80,160,240$ and $320 \mu \mathrm{g})$ and dosage of ${ }^{99 \mathrm{~m}} \mathrm{Tc}^{-\mathrm{O}_{4}}{ }^{-}(111,185,370$ and $555 \mathrm{MBq})$. The reaction was stopped by adding an excess of $1.0 \mathrm{~mol} / \mathrm{l}$ glycine. The labeling rate of ${ }^{99 \mathrm{~m}} \mathrm{Tc}-\mathrm{Hynic}-\mathrm{PEG}-\mathrm{AE} 105$ was detected by thin layer chromatography, as described previously (12). Each experiment was repeated 3 times. Hynic-PEG-AE105mut was labeled under the same conditions. The optimal conditions for the ${ }^{99 \mathrm{~m}} \mathrm{Tc}$ labeling of Hynic-PEG-AE105 and Hynic-PEG-AE105mut were as follows: $60 \mathrm{mg}$ Tricine and $1 \mathrm{ml}{ }^{99}{ }^{9} \mathrm{Tc}-\mathrm{O}_{4}{ }^{-}(\sim 10 \mathrm{mCi})$ in $80 \mu 1 \mathrm{~S}_{\mathrm{n}} \mathrm{CL}_{2} \bullet \mathrm{H}_{2} \mathrm{O}(1 \mathrm{mg} / \mathrm{ml})$ were diluted in $160 \mu 1$ Hynic-PEG-AE105 $(1 \mathrm{mg} / \mathrm{ml})$, followed by incubation at room temperature for $10 \mathrm{~min}$.

Purification of ${ }^{99 m}$ Tc-labeled peptides. ${ }^{99 \mathrm{~m}} \mathrm{Tc}$-labeled peptide was subsequently purified using Sep-Pak Light C18 cartridges (Waters Corporation, Milford, MA, USA), as described previously (13), and diluted with 8 volumes of water for injection. To determine the specific radioactivity of the labeled peptides, radioactivity was measured by a dose calibrator (CRC-25R; Capintec Inc., Ramsey, NJ, USA) following the manufacturer's instructions.

Pancreatic cancer xenografts in nude mice. The animal experiments were approved by the Institutional Animal Care and Use Committee (IACUC) of Dalian Medical University (Dalian, Liaoning, China). Sodium pentobarbital anesthesia was used to minimize animal suffering. Male nude mice (4-5 weeks old) were obtained from Dalian Medical University Animal Center, and kept under pathogen-free conditions in accordance with the guidelines of the IACUC of Dalian Medical University. For the xenograft tumor growth assay, BxPC-3 cells were obtained from the Chinese Academy of Sciences (Shanghai, China) and the cultured cells $\left(1 \times 10^{6}\right.$ cells) were injected subcutaneously into the right flank of the mice, which were anesthetized with $2 \%$ sodium pentobarbital (dose, $45 \mathrm{mg} / \mathrm{kg}$ weight). At 2 weeks post-inoculation, the tumor size was measured every 3-4 days until the tumors grew to a diameter of $10 \mathrm{~mm}$ or until the tumor burden exceeded $10 \%$ of their body weight, at which time the mice were enrolled in SPECT studies.
Table I. Radioactivity of ${ }^{99 \mathrm{~m}} \mathrm{Tc}-$ labeled peptides following incubation in saline.

\begin{tabular}{lcc}
\hline $\begin{array}{l}\text { Incubation } \\
\text { time }\end{array}$ & $\begin{array}{c}\text { Hynic-PEG- } \\
\text { AE105, \% }\end{array}$ & $\begin{array}{c}\text { Hynic-PEG- } \\
\text { AE105mut, \% }\end{array}$ \\
\hline $2 \mathrm{~h}$ & $96.14 \pm 1.26$ & $96.38 \pm 1.15$ \\
$4 \mathrm{~h}$ & $95.22 \pm 0.91$ & $95.27 \pm 1.43$ \\
$6 \mathrm{~h}$ & $94.93 \pm 1.12$ & $94.26 \pm 0.96$ \\
$8 \mathrm{~h}$ & $94.15 \pm 1.44$ & $93.66 \pm 0.83$
\end{tabular}

${ }^{99 \mathrm{~m}} \mathrm{Tc}$, technetium-99m.

Biodistribution studies. In brief, the nude mice bearing BxPC-3 xenografts were injected into the tail vein with $18.5 \mathrm{MBq}$ of ${ }^{99 m}$ Tc-Hynic-PEG-AE105 or ${ }^{99 m}$ Tc-Hynic-PEG-AE105mut. The mice were euthanized at $0.5,1,2,4$ or $8 \mathrm{~h}$ post-injection. Blood, tumor and major organs were collected (wet-weight) and the radioactivity was measured using a $\gamma$-counter (Perkin Elmer Inc., Waltham, MA, USA) ( $\mathrm{n}=5$ mice/group). Tumor/non-tumor (T/ NT) ratios were calculated based on the radioscans by outlining regions of equal areas of tumor tissues and the corresponding non-tumor tissues.

SPECT imaging.Prior to being sacrificed, all the mice underwent SPECT imaging (Millennium VG; GE Healthcare, Milwaukee, WI, USA), at 2, 4 and $6 \mathrm{~h}$ post-injection, respectively. The mice were laid in the center of the field of view. A low-energy high-resolution parallel holes collimator was used. SPECT images were obtained with a zoom factor of 3.0 for $5 \mathrm{~min}$, and were digitally stored in a 128x128 matrix and analyzed using a GE Integra workstation (GE Healthcare).

Immunohistochemistry (IHC). IHC was performed using a standard streptavidin-biotin-peroxidase complex method. In brief, non-specific binding was blocked with $10 \%$ normal rabbit serum for $20 \mathrm{~min}$. Tumor sections were deparaffinized and rehydrated. Endogenous peroxidase activity was blocked with $0.3 \%$ hydrogen peroxide for $20 \mathrm{~min}$. For antigen retrieval, the sections were microwave-treated in $10 \mathrm{mM}$ citrate buffer $(\mathrm{pH} \mathrm{6.0)}$ ) for $10 \mathrm{~min}$. The sections were incubated with rabbit uPAR polyclonal antibody (1:500 dilution; Santa Cruz Biotechnology Inc., Dallas, TX, USA) overnight, then incubated with a biotinylated goat anti-rabbit immunoglobulin $\mathrm{G}$ antibody $(1: 2,000$ dilution; Sigma-Aldrich, St. Louis, MO, USA) for $30 \mathrm{~min}$ and subsequently reacted with a streptavidin-peroxidase conjugate and 3-3'-diaminobenzidine (Sigma-Aldrich). The sections were counter-stained using Meyer's haematoxylin. Negative controls were performed by replacing the primary antibody with rabbit serum. The sections were observed under a light microscope and five fields (x400 magnification) of each section were randomly selected for analysis. The staining density was calculated based on absorbance using the Image-pro Plus 6.0 image analysis system (Media Cybernetics Inc., Rockville, MD, USA).

Statistical analysis. Statistical analysis was performed with SPSS software (version 10.0; SPSS Inc., Chicago, IL, USA). Data are presented as the mean \pm standard error of the mean and were 
Table II. Biodistribution and specificity of ${ }^{99 \mathrm{~m}}$ Tc-Hynic-PEG-AE105.

\begin{tabular}{|c|c|c|c|c|c|c|}
\hline \multirow[b]{2}{*}{ Location } & \multicolumn{6}{|c|}{ Radioactivity (\%ID/g) } \\
\hline & $0.5 \mathrm{~h}$ & $1 \mathrm{~h}$ & $2 \mathrm{~h}$ & $4 \mathrm{~h}$ & $6 \mathrm{~h}$ & $8 \mathrm{~h}$ \\
\hline Blood & $5.38 \pm 0.25$ & $3.74 \pm 0.43$ & $2.31 \pm 0.53$ & $2.87 \pm 0.13$ & $2.73 \pm 0.35$ & $2.44 \pm 0.22$ \\
\hline Tumor & $4.65 \pm 0.41$ & $3.96 \pm 0.26$ & $2.72 \pm 0.45$ & $3.12 \pm 0.27$ & $2.98 \pm 0.15$ & $2.15 \pm 0.29$ \\
\hline Heart & $3.43 \pm 0.51$ & $1.87 \pm 0.53$ & $1.37 \pm 0.20$ & $1.56 \pm 0.44$ & $1.71 \pm 0.48$ & $1.03 \pm 0.13$ \\
\hline Liver & $4.86 \pm 0.30$ & $3.86 \pm 0.61$ & $3.19 \pm 0.29$ & $2.99 \pm 0.65$ & $3.31 \pm 0.93$ & $2.09 \pm 0.20$ \\
\hline Spleen & $4.09 \pm 1.07$ & $1.41 \pm 0.70$ & $0.95 \pm 0.10$ & $1.61 \pm 0.74$ & $1.53 \pm 0.45$ & $0.93 \pm 0.06$ \\
\hline Pancreas & $3.74 \pm 0.47$ & $1.30 \pm 0.20$ & $1.12 \pm 0.72$ & $1.45 \pm 0.73$ & $1.30 \pm 0.41$ & $0.52 \pm 0.09$ \\
\hline Lung & $4.63 \pm 0.18$ & $3.46 \pm 1.70$ & $1.78 \pm 0.36$ & $2.06 \pm 0.23$ & $1.97 \pm 0.38$ & $1.39 \pm 0.36$ \\
\hline Kidney & $5.72 \pm 0.65$ & $4.35 \pm 0.28$ & $2.52 \pm 0.17$ & $3.21 \pm 0.21$ & $3.32 \pm 0.21$ & $2.50 \pm 0.37$ \\
\hline Stomach & $2.83 \pm 0.27$ & $1.46 \pm 0.42$ & $0.65 \pm 0.12$ & $1.23 \pm 0.42$ & $1.00 \pm 0.35$ & $0.54 \pm 0.02$ \\
\hline Intestine & $2.67 \pm 1.19$ & $1.18 \pm 0.65$ & $0.89 \pm 0.33$ & $1.28 \pm 0.88$ & $0.79 \pm 0.30$ & $0.46 \pm 0.03$ \\
\hline Bone & $2.32 \pm 0.36$ & $1.60 \pm 1.10$ & $0.56 \pm 0.12$ & $1.12 \pm 0.36$ & $1.34 \pm 0.47$ & $0.67 \pm 0.07$ \\
\hline Muscle & $1.60 \pm 0.34$ & $0.55 \pm 0.12$ & $0.40 \pm 0.07$ & $0.53 \pm 0.21$ & $0.49 \pm 0.08$ & $0.30 \pm 0.01$ \\
\hline Brain & $0.35 \pm 0.07$ & $0.35 \pm 0.31$ & $0.11 \pm 0.01$ & $0.14 \pm 0.05$ & $0.13 \pm 0.04$ & $0.08 \pm 0.01$ \\
\hline
\end{tabular}

${ }^{99 m} \mathrm{Tc}$, technetium-99m; ID, injected dose.

Table III. Biodistribution and specificity of ${ }^{99 \mathrm{~m}}$ Tc-Hynic-PEG-AE105mut.

\begin{tabular}{|c|c|c|c|c|c|c|}
\hline \multirow[b]{2}{*}{ Location } & \multicolumn{6}{|c|}{ Radioactivity (\%ID/g) } \\
\hline & $0.5 \mathrm{~h}$ & $1 \mathrm{~h}$ & $2 \mathrm{~h}$ & $4 \mathrm{~h}$ & $6 \mathrm{~h}$ & $8 \mathrm{~h}$ \\
\hline Blood & $4.16 \pm 0.79$ & $2.82 \pm 0.68$ & $3.20 \pm 0.20$ & $1.56 \pm 0.47$ & $1.53 \pm 0.23$ & $1.33 \pm 0.22$ \\
\hline Tumor & $3.53 \pm 0.42$ & $2.53 \pm 0.87$ & $3.21 \pm 0.29$ & $1.65 \pm 0.53$ & $1.41 \pm 0.38$ & $1.21 \pm 0.20$ \\
\hline Heart & $2.54 \pm 0.28$ & $2.11 \pm 0.67$ & $2.46 \pm 0.31$ & $1.25 \pm 0.46$ & $1.21 \pm 0.28$ & $1.01 \pm 0.28$ \\
\hline Liver & $3.92 \pm 0.33$ & $2.92 \pm 1.31$ & $3.52 \pm 0.63$ & $3.26 \pm 1.33$ & $1.90 \pm 1.81$ & $1.65 \pm 0.87$ \\
\hline Spleen & $2.71 \pm 0.05$ & $2.04 \pm 0.90$ & $2.96 \pm 0.80$ & $2.15 \pm 1.29$ & $0.96 \pm 0.69$ & $0.82 \pm 0.20$ \\
\hline Pancreas & $1.74 \pm 0.09$ & $1.50 \pm 0.38$ & $1.55 \pm 0.18$ & $0.75 \pm 0.08$ & $0.88 \pm 0.49$ & $0.73 \pm 0.26$ \\
\hline Lung & $1.82 \pm 0.12$ & $1.62 \pm 0.11$ & $1.57 \pm 0.21$ & $1.37 \pm 0.51$ & $1.12 \pm 0.17$ & $1.00 \pm 0.18$ \\
\hline Kidney & $4.41 \pm 0.59$ & $3.07 \pm 0.66$ & $3.47 \pm 0.33$ & $2.41 \pm 0.41$ & $2.28 \pm 0.26$ & $2.03 \pm 0.40$ \\
\hline Stomach & $1.57 \pm 0.26$ & $1.37 \pm 0.19$ & $1.82 \pm 0.55$ & $0.70 \pm 0.19$ & $0.47 \pm 0.18$ & $0.42 \pm 0.13$ \\
\hline Intestine & $2.45 \pm 0.27$ & $2.36 \pm 0.31$ & $2.60 \pm 1.04$ & $0.56 \pm 0.10$ & $0.66 \pm 0.27$ & $0.61 \pm 0.20$ \\
\hline Bone & $1.79 \pm 0.34$ & $1.59 \pm 0.45$ & $1.70 \pm 0.33$ & $0.69 \pm 0.19$ & $0.56 \pm 0.05$ & $0.56 \pm 0.21$ \\
\hline Muscle & $0.89 \pm 0.05$ & $0.72 \pm 0.20$ & $0.80 \pm 0.19$ & $0.54 \pm 0.21$ & $0.36 \pm 0.10$ & $0.31 \pm 0.10$ \\
\hline Brain & $0.34 \pm 0.05$ & $0.18 \pm 0.15$ & $0.24 \pm 0.03$ & $0.08 \pm 0.03$ & $0.08 \pm 0.02$ & $0.07 \pm 0.01$ \\
\hline
\end{tabular}

${ }^{99 \mathrm{~m}} \mathrm{Tc}$, technetium-99m; ID, injected dose.

assessed by a two-tailed Student's t-test. $\mathrm{P}<0.05$ was used to indicate a statistically significant difference. The correlation between tracer and uPAR expression was analyzed using Pearson's $\chi^{2}$ test.

\section{Results}

Radiolabeling of peptides. The efficiency of the ${ }^{99 \mathrm{~m}} \mathrm{Tc}$ labeling of Hynic-PEG-AE105 and inactive Hynic-PEG-AE105 was $94.64 \pm 0.72$ and $92.03 \pm 0.81 \%$, respectively. The optimal conditions for the ${ }^{99 \mathrm{~m}} \mathrm{Tc}$ labeling of Hynic-PEG-AE105 and Hynic-PEG-AE105mut were as follows: $60 \mathrm{mg}$ Tricine and $1 \mathrm{ml}$
${ }^{99 \mathrm{~m}} \mathrm{Tc}^{-\mathrm{O}_{4}}{ }^{-}(\sim 10 \mathrm{mCi})$ in $80 \mu 1 \mathrm{~S}_{\mathrm{n}} \mathrm{CL}_{2} \cdot \mathrm{H}_{2} \mathrm{O}(1 \mathrm{mg} / \mathrm{ml})$ were diluted in $160 \mu \mathrm{l}$ Hynic-PEG-AE105 $(1 \mathrm{mg} / \mathrm{ml})$, followed by incubation at room temperature for $10 \mathrm{~min}$. The radiochemical purity of ${ }^{99 \mathrm{~m}}$ Tc-Hynic-PEG-AE105 and ${ }^{99 \mathrm{~m}}$ Tc-Hynic-PEG-AE105mut was $97.72 \pm 1.73$ and $96.70 \pm 1.32 \%$, respectively, following Sep-Pak purification (Fig. 1). No significant degradation of any ${ }^{99} \mathrm{~m}$ Tc-labeled peptides was observed in physiological saline following incubation for $8 \mathrm{~h}$ (Table I).

Biodistribution and specificity of ${ }^{99 m}$ Tc-Hynic-PEG-AE105. Next, the study investigated the in vivo pharmacokinetics of 


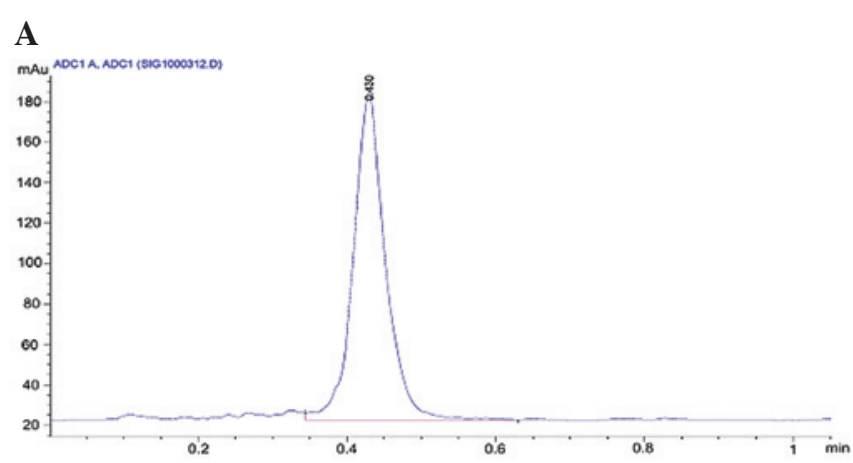

B

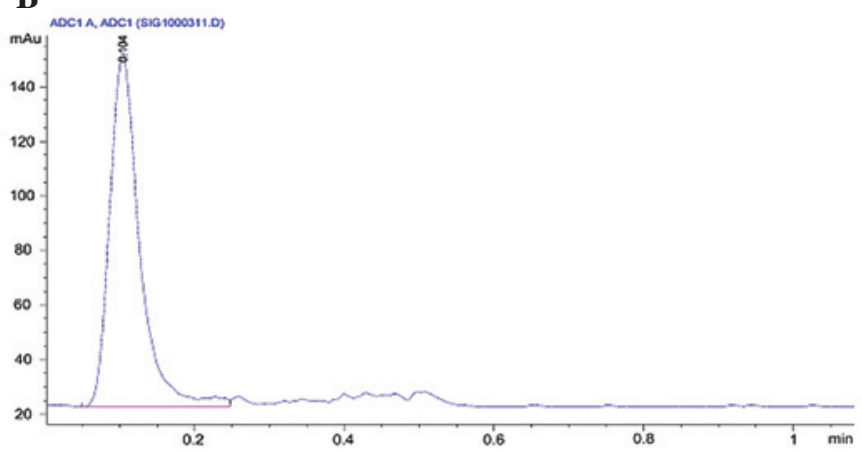

Figure 1. Radiochemical purity of technetium- $99 \mathrm{~m}\left({ }^{99 \mathrm{~m}} \mathrm{Tc}\right)$-labled peptides. The peptides were purified by Sep-Pak and then analyzed by thin layer chromatography (TLC). (A) TLC pattern of $99^{\mathrm{m}} \mathrm{Tc}-\mathrm{Hynic}-\mathrm{PEG}-\mathrm{AE} 105$. (B) TLC pattern of $99^{\mathrm{m}} \mathrm{Tc}-\mathrm{Hynic}-\mathrm{PEG}-\mathrm{AE} 105 \mathrm{mut}$. The peaks indicate labeled peptides.

$\mathbf{A}$

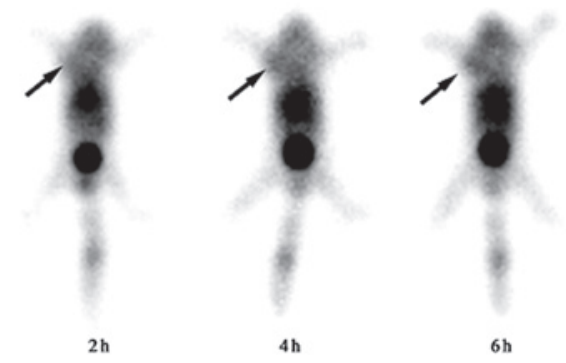

B

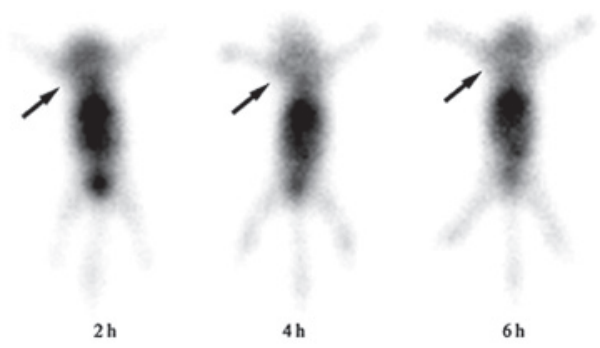

Figure 2. In vivo imaging of xenografted nude mice. (A) Coronal singlephoton emission computed tomography (SPECT) images of mice bearing BxPC-3 tumors at 2, 4 and $6 \mathrm{~h}$ post-injection of $99^{\mathrm{m}} \mathrm{Tc}-\mathrm{Hynic}-\mathrm{PEG}-\mathrm{AE} 105$. (B) Coronal SPECT images of mice bearing BxPC-3 tumors at 2, 4 and $6 \mathrm{~h}$ post-injection of ${ }^{99 \mathrm{~m}} \mathrm{Tc}-\mathrm{Hynic}-\mathrm{PEG}-\mathrm{AE} 105 \mathrm{mut}$. The arrows indicate xenografted tumors. ${ }^{99 \mathrm{~m}} \mathrm{Tc}$, technetium-99m.

${ }^{99 m}$ Tc-Hynic-PEG-AE105 and ${ }^{99 m}$ Tc-Hynic-PEG-AE105 in pancreatic cancer BxPC-3 cell-bearing animals. A fast clearance rate of radiolabeled peptides from the blood and all organs investigated following resection was found (Tables II and III).

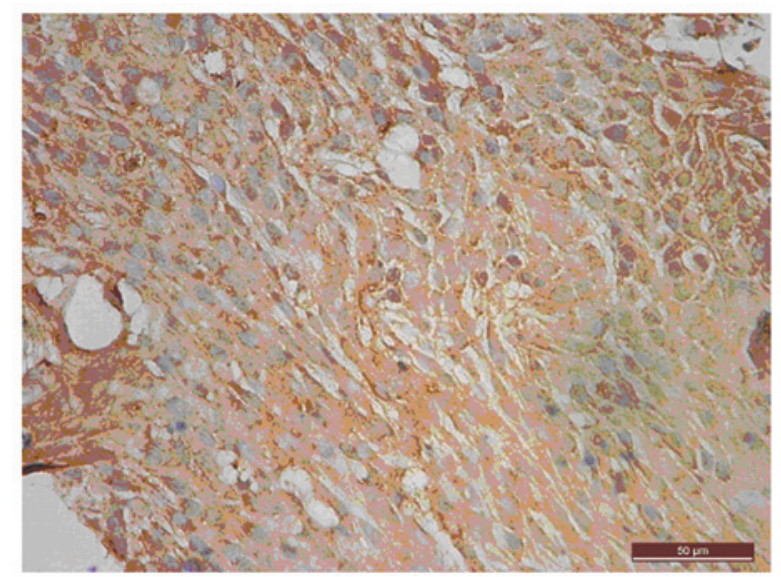

Figure 3. Immunohisotchemical staining of urokinase-type plasminogen activator receptor (uPAR) in xenografts. uPAR was mainly stained in the cytoplasm and on the membrane surface of BxPC-3 cells (brown).

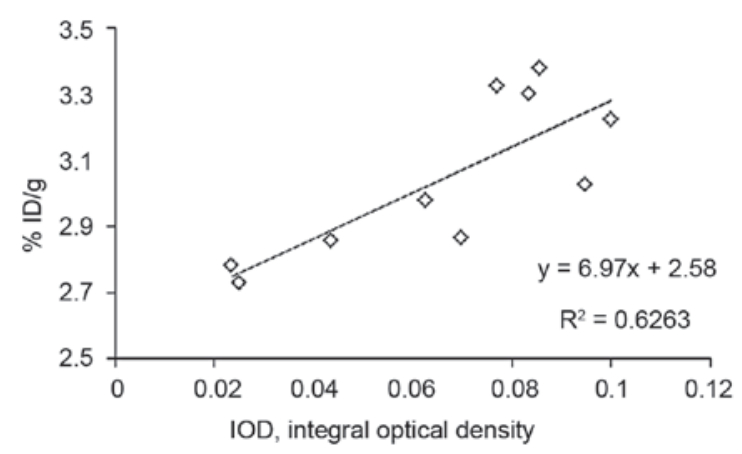

Figure 4. uPAR expression is significantly correlated with the uptake of $99^{\mathrm{m}}$ Tc-Hynic-PEG-AE105 in tumors at 4 to $6 \mathrm{~h}(\mathrm{n}=10 ; \mathrm{r}=0.791, \mathrm{P}=0.006)$ Intergrated optical density indicated the relative UPAR protein level based on immunohistochemistry analysis. UPAR, urokinase-type plasminogen activator receptor; ${ }^{99 \mathrm{~m}} \mathrm{Tc}$, technetium-99m; ID, injected dose.

The two radiolabeled peptides were distributed to the various organs of the body and cleared rapidly from the blood, primarily via the hepatic-intestinal route and kidneys. The tumor uptake of ${ }^{99 m}$ Tc-Hynic-PEG-AE105 was significantly higher than the normal pancreatic tissue uptake at $4 \mathrm{~h}$ and $6 \mathrm{~h}$ post-injection $(\mathrm{P}<0.01)$, whereas the uptake in the blood was $2.87 \pm 0.13(4 \mathrm{~h}) / 2.73 \pm 0.35(6 \mathrm{~h})$, and the uptake in the muscle was $0.53 \pm 0.21(4 \mathrm{~h}) / 0.49 \pm 0.08(4 \mathrm{~h})$, thus generating a tumor-to-blood and tumor-to-muscle ratio of $1.09 \pm 0.12(4 \mathrm{~h}) / 1.11 \pm 0.20(6 \mathrm{~h})$ and $6.29 \pm 1.59(4 \mathrm{~h}) / 6.26 \pm 1.20(6 \mathrm{~h})$, respectively. The tumor uptake of the control peptide, ${ }^{99 \mathrm{~m}}$ Tc-Hynic-PEG-AE105mut, at 4 or $6 \mathrm{~h}$ was significantly reduced to $1.65 \pm 0.53(4 \mathrm{~h})$ and $1.41 \pm 0.38(6 \mathrm{~h})(\mathrm{P}<0.01)$, respectively, indicating the specificity of ${ }^{99 m}$ Tc-Hynic-PEG-AE105 to human uPAR.

SPECT study. The BxPC-3 tumor-bearing mice were SPECT-scanned at 2, 4 and $6 \mathrm{~h}$ post-intravenous injection of ${ }^{99 \mathrm{~m}}$ Tc-Hynic-PEG-AE or ${ }^{99 \mathrm{~m}}$ Tc-Hynic-PEG-AE105mut. The representative images for each group of mice at 2, 4 and $6 \mathrm{~h}$ post-injection are shown in Fig. 2. The tumor was clearly visible as early as $2 \mathrm{~h}$ post-injection of ${ }^{99 \mathrm{~m}}$ Tc-Hynic-PEG-AE105, and the uptake kept increasing and reached a plateau at $6 \mathrm{~h}$ post-injection. By contrast, in the mice injected with 
${ }^{99}$ Tc-Hynic-PEG-AE105mut, the tumor was not clear at 2, 4 and $6 \mathrm{~h}$ post-injection. Using quantitative region of interest analysis, a significantly higher radioactive uptake ratio (T/NT) was found for ${ }^{99} \mathrm{~m}$ Tc-Hynic-PEG-AE105 than for control peptide ${ }^{99 \mathrm{~m}} \mathrm{Tc}-\mathrm{Hynic}-\mathrm{PEG}-\mathrm{AE} 105 \mathrm{mut}$ at $4 \mathrm{~h}(3.37 \pm 0.11$ vs. $1.36 \pm 0.18 ; \mathrm{P}<0.001)$ and $6 \mathrm{~h}$ (3.64 \pm 0.25 vs. $1.28 \pm 0.20 ; \mathrm{P}<0.001)$.

UPAR expression is correlated with the tumor uptake of ${ }^{99 m}$ Tc-Hynic-PEG-AE105. IHC showed that UPAR was mainly stained in the cytoplasm and on the membrane surface of the BxPC-3 cells (Fig. 3). Semi-quantification of UPAR staining showed that UPAR expression was not significantly different between the experimental and control groups $(0.481 \pm 0.024$ vs. $0.574 \pm 0.021 ; \mathrm{P}=0.173)$. By association analysis, a significant correlation was found between the tumor uptake of ${ }^{99 \mathrm{~m}}$ Tc-Hynic-PEG-AE105 and uPAR expression at 4 to $6 \mathrm{~h}$ post-injection $(\mathrm{r}=0.791, \mathrm{P}=0.006$; Fig. 4$)$.

\section{Discussion}

In the present study, ${ }^{99 \mathrm{~m}}$ Tc-labeled Hynic-PEG-AE105 was introduced as a SPECT tracer for imaging of uPAR expression for the first time. ${ }^{99 \mathrm{~m} T c-H y n i c-P E G-A E 105}$ exhibited high affinity and specificity to UPAR in vivo, and UPAR expression was significantly correlated with the uptake of ${ }^{99 m}$ Tc-Hynic-PEG-AE105 in the pancreatic cancer xenograft mouse model.

Despite its relatively low incidence, pancreatic cancer ranks fourth in the number of cancer mortalities each year (14). Overall, $<5 \%$ of individuals will survive 5 years beyond their diagnosis (15). Therefore, novel and improved therapy options are required. Recent studies demonstrated that RNAi-mediated uPAR-knockdown was able to retard the invasive ability and angiogenic potential of cancer cells in vitro and in vivo $(5,8,9)$. These results suggest that the targeting of UPAR has significant therapeutic potential for the treatment of pancreatic cancer. For the potential clinical application of anticancer therapy based on the UPA/uPAR system, we sought to develop a non-invasive imaging method for the detection of pancreatic cancer based on UPAR expression.

Previous studies investigated the use of a high-affinity 9-mer peptide antagonist of the UPA-uPAR (AE105) for positron emission tomography (PET) imaging of UPAR expression, and showed that copper-64 $\left({ }^{64} \mathrm{Cu}\right)$-labeled DOTA-AE105 exhibited specific and high-affinity binding to UPAR in vitro and in vivo (16-18). However, the clinical application of this protocol is restricted due to the limited availability of ${ }^{64} \mathrm{Cu}$ and the high cost of PET imaging. ${ }^{99 \mathrm{~m}} \mathrm{Tc}$ is a nuclear isomer of ${ }^{99} \mathrm{Tc}$ that is detectable within the body using medical equipment such as $\gamma$-ray cameras, which emit readily detectable CXL keV $\gamma$ rays (the same wavelength as emitted by conventional X-ray equipment), and the half-life for $\gamma$ emission is only $6 \mathrm{~h}$ (19). Safe and fast scanning procedures are a result of the relatively short physical half-life of ${ }^{99} \mathrm{Tc}$ and its biological half-life of 1 day in terms of human activity and metabolism (20). Therefore, ${ }^{99 \mathrm{~m}} \mathrm{Tc}$-labeled peptides have been used for in vivo targeting of tumors, including pancreatic cancer (21-23).

In the present study, ${ }^{99 \mathrm{~m}} \mathrm{Tc}-$ labeled peptide was employed for SPECT imaging of UPAR in pancreatic cancer. First, the conditions for the ${ }^{99 \mathrm{~m}}$ Tc labeling of Hynic-PEG-AE105 and Hynic-PEG-AE105 were optimized. It was found that under the conditions optimized, the radiochemical purity of ${ }^{99 \mathrm{~m}}$ Tc-Hynic-PEG-AE105 was $97.72 \pm 1.73 \%$ following Sep-Pak purification. Similarly, the radiochemical purity of 99mTc-Hynic-PEG-AE105mut was 96.70 $\pm 1.32 \%$.

UPAR is widely expressed in pancreatic cancer cells such as Panc-1, MIA PaCa-2 and BxPC-3 (24). Preliminary experiments in the present study showed that among these cell lines, the expression level of uPAR is the highest in the BxPC-3 cell line (data not shown), thus BxPC-3 cells were chosen for further analysis. To analyze the biodistribution and specificity of ${ }^{99 m}$ Tc-Hynic-PEG-AE105 in vivo, a nude mouse xenografted with BxPC-3 cells was used as the animal model. It was found that the distribution of radioactivity in the tumor tissue was significantly higher than that in the normal tissue. Taken together, these data demonstrate the specificity of ${ }^{99 \mathrm{~m}} \mathrm{Tc}-\mathrm{Hynic}-\mathrm{PEG}-\mathrm{AE} 105$ for pancreatic cancer cells that highly express UPAR.SPECT imaging of nude mice further confirms the sensitivity and specificity of 99mTc-Hynic-PEG-AE105. The tumor xenograft was clearly visible as early as $2 \mathrm{~h}$ post-injection of ${ }^{99 \mathrm{~m}} \mathrm{Tc}-\mathrm{Hynic}-\mathrm{PEG}-\mathrm{AE} 105$, and the uptake kept increasing and reached a plateau at $6 \mathrm{~h}$ post-injection. In addition, a significant correlation was found between the tumor uptake of ${ }^{99 \mathrm{~m}}$ Tc-Hynic-PEG-AE105 and UPAR expression in the xenografted tumors, thus providing a strong argument for the specificity of ${ }^{99 \mathrm{~m}}$ Tc-Hynic-PEG-AE105.

However, the blood clearance rate of ${ }^{99 \mathrm{~m} T c-A E 105}$ is not fast enough, leading to continued retention of the tracer in the blood, liver and kidneys, and interference in detecting the tumor lesion. Therefore, further studies are required to speed up the rate of the blood clearance of ${ }^{99 \mathrm{~m}} \mathrm{Tc}-\mathrm{AE} 105$ and improve the imaging of the target/background ratio.

In summary, the present study reported the radiosynthesis of ${ }^{99 \mathrm{~m}}$ Tc-Hynic-PEG-AE105 and achieved a high yield of ${ }^{99 \mathrm{~m}} \mathrm{Tc}$ labeling of Hynic-PEG-AE105. Significantly, it was demonstrated that the distribution of ${ }^{99 \mathrm{~m}} \mathrm{Tc}-\mathrm{Hynic}-\mathrm{PEG}-\mathrm{AE} 105$ in the xenografted tumor tissue was correlated with the level of uPAR expression in pancreatic cancer. ${ }^{99 \mathrm{~m}}$ Tc-Hynic-PEG-AE105 is a promising agent for the non-invasive determination of uPAR expression in pancreatic cancer.

\section{Acknowledgements}

This study was funded by the National Natural Science Foundation of China (grant no. 81071173).

\section{References}

1. Torre LA, Bray F, Siegel RL, Ferlay J, Lortet-Tieulent J and Jemal A: Global cancer statistics, 2012. CA Cancer J Clin 65: 87-108, 2015.

2. Ryan DP, Hong TS and Bardeesy N: Pancreatic adenocarcinoma. N Engl J Med 371: 2140-2141, 2014.

3. Parikh PY and Lillemoe KD: Surgical management of pancreatic cancer - distal pancreatectomy. Semin Oncol 42: 110-122, 2015.

4. Rombouts SJ, Vogel JA, van Santvoort HC, van Lienden KP, van Hillegersberg R, Busch OR, Besselink MG and Molenaar IQ: Systematic review of innovative ablative therapies for the treatment of locally advanced pancreatic cancer. Br J Surg 102: 182-193, 2015.

5. Gorantla B, Asuthkar S, Rao JS, Patel J and Gondi CS: Suppression of the uPAR-uPA system retards angiogenesis, invasion and in vivo tumor development in pancreatic cancer cells. Mol Cancer Res 9: 377-389, 2011. 
6. Sorio C, Mafficini A, Furlan F, Barbi S, Bonora A, Brocco G, Blasi F, Talamini G, Bassi C and Scarpa A: Elevated urinary levels of urokinase-type plasminogen activator receptor (UPAR) in pancreatic ductal adenocarcinoma identify a clinically high-risk group. BMC Cancer 11: 448, 2011.

7. Khoi PN, Xia Y, Lian S, Kim HD, Kim do H, Joo YE, Chay KO, Kim KK and Jung YD: Cadmium induces urokinase-type plasminogen activator receptor expression and the cell invasiveness of human gastric cancer cells via the ERK-1/2, NF- $\mathrm{BB}$ and AP-1 signaling pathways. Int J Oncol 45: 1760-1768, 2014.

8. Kotipatruni RR, Nalla AK, Asuthkar S, Gondi CS, Dinh DH and Rao JS: Apoptosis induced by knockdown of uPAR and MMP-9 is mediated by inactivation of EGFR/STAT3 signaling in medulloblastoma. PLoS One 7: e44798, 2012.

9. Zhuo J, Tan EH, Yan B, Tochhawng L, Jayapal M, Koh S, Tay HK, Maciver SK, Hooi SC, Salto-Tellez M, et al: Gelsolin induces colorectal tumor cell invasion via modulation of the urokinase-type plasminogen activator cascade. PLoS One 7: e43594, 2012.

10. Knör S, Sato S, Huber T, Morgenstern A, Bruchertseifer F, Schmitt M, Kessler H, Senekowitsch-Schmidtke R, Magdolen V and Seidl C: Development and evaluation of peptidic ligands targeting tumour-associated urokinase plasminogen activator receptor (UPAR) for use in alpha-emitter therapy for disseminated ovarian cancer. Eur J Nucl Med Mol Imaging 35: 53-64, 2008.

11. Liu D, Overbey D, Watkinson L and Giblin MF: Synthesis and characterization of an (111) In-labeled peptide for the in vivo localization of human cancers expressing the urokinase-type plasminogen activator receptor (uPAR). Bioconjug Chem 20: 888-894, 2009

12. Daozhen C, Lu L, Min Y, Xinyu J and Ying H. Synthesis of (131) I-labeled-[(131)I]iodo-17-allylamino-17-demethoxy geldanamycin ([(131)I]iodo-17-AAG) and its biodistribution in mice. Cancer Biother Radiopharm 22: 607-612, 2007.

13. McPherson DW and Knapp FF Jr: A rapid and simple Sep Pak method for purification of radioiodinated IQNP, a high affinity ligand for the muscarinic receptor. Nucl Med Biol 26: 859-863, 1999.

14. Siegel R, Naishadham D and Jemal A: Cancer statistics, 2013. CA Cancer J Clin 63: 11-30, 2013.

15. Michl P and Gress TM: Current concepts and novel targets in advanced pancreatic cancer. Gut 62: 317-326, 2013.
16. Persson M, Madsen J, Østergaard S, Jensen MM, Jørgensen JT, Juhl K, Lehmann C, Ploug M and Kjaer A: Quantitative PET of human urokinase-type plasminogen activator receptor with 64Cu-DOTA-AE105: Implications for visualizing cancer invasion. J Nucl Med 53: 138-145, 2012.

17. Li ZB, Niu G, Wang H, He L, Yang L, Ploug M and Chen X: Imaging of urokinase-type plasminogen activator receptor expression using a $64 \mathrm{Cu}$-labeled linear peptide antagonist by microPET. Clin Cancer Res 14: 4758-4766, 2008.

18. Persson M, Madsen J, Østergaard S, Ploug M and Kjaer A: 68Ga-labeling and in vivo evaluation of a uPAR binding DOTA- and NODAGA-conjugated peptide for PET imaging of invasive cancers. Nucl Med Biol 39: 560-569, 2012.

19. Younes CK, Boisgard R and Tavitian B: Labelled oligonucleotides as radiopharmaceuticals: Pitfalls, problems and perspectives. Curr Pharm Des 8: 1451-1466, 2002.

20. Lindberg H, Hofström C, Altai M, Honorvar H, Wållberg H, Orlova A, Ståhl S, Gräslund T and Tolmachev V: Evaluation of a HER2-targeting affibody molecule combining an N-terminal HEHEHE-tag with a GGGC chelator for 99mTc-labelling at the $\mathrm{C}$ terminus. Tumour Biol 33: 641-651, 2012.

21. Nock B and Maina T: Tetraamine-coupled peptides and resulting (99m)Tc-radioligands: An effective route for receptor-targeted diagnostic imaging of human tumors. Curr Top Med Chem 12: 2655-2667, 2012

22. Spanu A, Farris A, Chessa F, Sanna D, Pittalis M, Manca A and Madeddu G: Planar scintimammography and SPECT in neoadjuvant chemo or hormonotherapy response evaluation in locally advanced primary breast cancer. Int J Oncol 32: 1275-1283, 2008.

23. Cyran CC, Paprottka PM, Eisenblätter M, Clevert DA, Rist C, Nikolaou K, Lauber K, Wenz F, Hausmann D, Reiser MF, et al: Visualization, imaging and new preclinical diagnostics in radiation oncology. Radiation Oncology 9: 3, 2014.

24. Gorantla B, Asuthkar S, Rao JS, Patel J and Gondi CS: Suppression of the uPAR-uPA system retards angiogenesis, invasion and in vivo tumor development in pancreatic cancer cells. Mol Cancer Res 9: 377-389, 2011. 